\title{
Mobiluncus gen. nov., Mobiluncus curtisii subsp. curtisii sp. nov., Mobiluncus curtisii subsp. holmesii subsp. nov., and Mobiluncus mulieris sp. nov., Curved Rods from the Human Vagina
}

\author{
CAROL A. SPIEGEL ${ }^{1 *}$ AND MARILYN ROBERTS ${ }^{2}$ \\ Department of Surgery, The Medical College of Wisconsin, Milwaukee, Wisconsin 53226, ${ }^{1}$ and Department of Pediatrics \\ RD-20, University of Washington, Seattle, Washington $98195^{2}$
}

\begin{abstract}
A total of 22 strains of curved, anaerobic bacteria from the vaginae of women with bacterial vaginosis were found to be morphologically, biochemically, and genetically distinct from species in previously described genera. We placed these organisms in the genus Mobiluncus gen. nov., which includes curved, anaerobic, motile, rod-shaped bacteria that have multiple subpolar flagella and multilayered gram-variable cell walls, produce succinate and acetate, are stimulated by rabbit serum, and have guanine-plus-cytosine contents of 49 to $52 \mathrm{~mol} \%$. Mobiluncus curtisii is the type species (type strain, ATCC 35241). Mobiluncus curtisii strains are small (length, $1.7 \mu \mathrm{m}$ ) and gram variable, are stimulated by arginine, and produce ornithine, citrulline, and ammonia from arginine. Six of these strains migrate through soft $(0.25 \%)$ agar and are nitrate negative, and these organisms are designated Mobiluncus curtisii subsp. curtisii. Six strains that do not migrate through soft agar and are nitrate positive are designated Mobiluncus curtisii subsp. holmesii (type strain, ATCC 35242). A total of 10 strains are designated Mobiluncus mulieris (type strain, ATCC 35243). These organisms are large (length, $2.9 \mu \mathrm{m})$ and gram negative, produce acid $(\mathrm{pH}<5.5)$ from glycogen, and are CAMP test positive. The levels of deoxyribonucleic acid homology were $>75 \%$ within and $\leq 25 \%$ between strains of the two species.
\end{abstract}

Vibrio-like organisms were observed in vaginal fluids as early as 1895 (19) and were first isolated from the female genital tract by Curtis in 1913 (6). Prévot (26) described "Vibrio mulieris," the Vibrio of Curtis, in 1940. In 1954, Moore described five strains (22) which grew best in an anaerobic environment supplemented with $\mathrm{CO}_{2}$. Durieux and Dublanchet (7) characterized 18 serum-requiring strains of "vibrions succinoproducteurs" and separated these organisms into two groups, group VSP 1 containing cells which were 2 to $3 \mu \mathrm{m}$ long, did not ferment glucose, and varied in nitrate reductase activity and group VSP 2 containing cells which were 5 to $6 \mu \mathrm{m}$ long and fermented glucose but did not reduce nitrate. Peloux and Thomas (23) characterized four vaginal strains which were large (length, 5 to $6 \mu \mathrm{m}$ ) and saccharolytic. The guanine-plus-cytosine $(\mathrm{G}+\mathrm{C})$ content of one of these strains was 55 mol\%. Recently Hjelm et al. (12) characterized 11 strains which fermented glucose, Holst et al. (14) studied 35 strains which were asaccharolytic, and Sprott et al. (35) examined 20 strains, including 8 short curved rods which utilized maltose, hydrolyzed hippurate, and hydrolyzed arginine and 12 long curved rods which were negative for all three of these characters.

Curved motile rod-shaped bacteria are of interest because they are associated with bacterial vaginosis (formerly known as nonspecific vaginitis) $(9,11,24,25,29,33,34)$. However, previously published descriptions have been incomplete and inconsistent, and the taxonomic position of these organisms is uncertain. The purpose of this study was to characterize our strains and compare them with similar strains from other investigators, as well as with phenotypically similar species in previously described genera. The vaginal strains are distinct from previously described genera, and we propose that they be placed in two species in the genus Mobiluncus gen. nov.

(Some of the results were presented at the 83rd Annual

\footnotetext{
* Corresponding author.
}

Meeting of the American Society for Microbiology, New Orleans, La., 1983.)

\section{MATERIALS AND METHODS}

Sources and maintenance of strains. We studied 22 strains of vaginal curved rod-shaped bacteria from 22 women who had clinical diagnoses of bacterial vaginosis, as determined by standard criteria (1). The curved motile rod-shaped organisms with strain designations beginning with BV (bacterial vaginosis) and SV (study of vaginosis) were isolated from vaginal fluids that were collected by methods described previously (32). The strains were isolated on brain heart infusion medium (Difco Laboratories, Detroit, Mich.) supplemented with $2 \%$ agar, $5 \%$ sheep erythrocytes, and $2 \%$ proteose peptone no. 3 or on brucella agar (Difco) supplemented with $5 \%$ sheep erythrocytes. The strains with designations beginning with $\mathrm{BV}$ were isolated by one of us (C.A.S.) from women in Seattle, Wash., and have been described briefly elsewhere (34). The strains with designations beginning with SV were provided by S. M. Finegold and Ellen Baron, Wadsworth Veterans Administration Hospital, Los Angeles, Calif. The remaining three strains were provided by Peter Piot, Institute for Tropical Medicine, Antwerp, Belgium. The sources of the other organisms studied were as follows: Wolinella recta FDC 285, Wolinella sp. strain FDC 286, Bacteroides gracilis FDC 401, and Campylobacter concisus FDC $484^{\mathrm{T}}(\mathrm{T}=$ type strain) were from Anne C. R. Tanner, Forsyth Dental Center, Boston, Mass.; strain VSMC, a Wolinella succinogenes-like organism of human origin, was from Marie B. Coyle, University of Washington, Seattle; Succinivibrio dextrinosolvens Bryant 24 was from M. P. Bryant, University of Illinois, Urbana; Eubacterium lentum A238-5 was isolated by one of us (C.A.S.) from a perforated appendix; and Actinomyces odontolyticus ATCC $17929^{\mathrm{T}}$, Actinomyces bovis ATCC $13683^{\mathrm{T}}$, Anaerovibrio lipolytica ATCC $33276^{\mathrm{T}}$, Anaerobiospirillum succiniciproducens ATCC $29305^{\mathrm{T}}$, Campylobacter 
fetus subsp. venerealis ATCC $19438^{\mathrm{T}}$, and Selenomonas sputigena ATCC $33150^{\mathrm{T}}$ were obtained from the American Type Culture Collection, Rockville, Md.

The strains were stored in double-strength skim milk at -20 or $-70^{\circ} \mathrm{C}$ and were used within five passages of recovery from frozen stocks for each experiment.

Biochemical characterization. Media were inoculated and incubated in an anaerobic environment containing $80 \%$ nitrogen, $10 \%$ carbon dioxide, and $10 \%$ hydrogen. The cultures were incubated at $35^{\circ} \mathrm{C}$ for 5 days unless indicated otherwise. All media except starch broth, McClung-Toabe agar, and brucella blood agar were supplemented with $2 \%$ rabbit serum (GIBCO Laboratories, Grand Island, N.Y.) unless indicated otherwise. For some experiments broth media were supplemented with $1.8 \mathrm{mg}$ of formate per $\mathrm{ml}$ and $1.8 \mathrm{mg}$ of fumarate per ml (13) instead of rabbit serum.

Fermentation reactions, meat digestion, nitrate reduction, esculin and gelatin hydrolysis, and $\mathrm{H}_{2} \mathrm{~S}$ production were determined in prereduced anaerobically sterilized media (PRAS II media; Scott Laboratories, Fiskeville, R.I.). Fermentation reactions were tested in peptone-yeast extract (PY) broth supplemented with the appropriate carbon sources (13). Production of lipase and lecithinase was determined on McClung-Toabe agar (Regional Media Laboratories, Lenexa, Kans.). Production of ammonia, lipase, lecithinase, indole, $\mathrm{H}_{2} \mathrm{~S}$, and catalase, hydrolysis of gelatin and esculin, and digestion of meat were determined by the methods described in the Anaerobe Laboratory Manual (13). $\mathrm{H}_{2} \mathrm{~S}$ production was determined in SIM medium (PRAS II medium) by using lead acetate strips (BBL Microbiology Systems, Cockeysville, Md.). Hippurate hydrolysis was determined by gas-liquid chromatography (17) after growth in PY broth supplemented with $5 \mathrm{mg}$ of hippurate (Sigma Chemical Co., St. Louis, Mo.) per $\mathrm{ml}$ instead of rabbit serum.

Columbia broth (Difco) supplemented with $1 \%$ soluble starch (Difco), $10 \mu \mathrm{g}$ of resazurin per $/ \mathrm{ml}$, and $2 \%$ rabbit serum was designated CSS broth. CSS broth was further supplemented with $1.5 \%$ agar (CSS agar) or $0.25 \%$ agar (CSS soft agar) for some experiments. Growth was evaluated in anaerobic, microaerophilic, capnophilic, and aerobic environments at $35^{\circ} \mathrm{C}$ and in an anaerobic environment at 25,42 , and $45^{\circ} \mathrm{C}$ on CSS agar. Plates to be incubated anaerobically were placed in GasPak jars (BBL) before removal from the chamber. A microaerophilic environment was obtained by evacuating a GasPak jar to a pressure of $20 \mathrm{lb} / \mathrm{in}^{2}$ and refilling it twice with nitrogen and once with $80 \%$ nitrogen$10 \%$ hydrogen-10\% carbon dioxide in the absence of catalyst. A capnophilic environment was created in sealed Mylar bags filled with $10 \% \mathrm{CO}_{2}$ in air. Aerobic plates were incubated in Mylar bags filled with air.

Synergistic hemolysis was determined by a modification of the CAMP test (8), using brucella agar supplemented with $5 \%$ sheep blood (Regional Media Labs) and Staphylococcus aureus ATCC 25923. Brucella agar (Difco) was supplemented with horse blood or rabbit blood (GIBCO).

Enzyme production was evaluated by using API ZYM test strips (Analytab Products, Plainview, N.Y.). Cultures were grown for 4 days at 35 or $42^{\circ} \mathrm{C}$ in CSS broth. The cells were harvested by centrifugation, washed twice with sterile saline, resuspended in saline, and adjusted to an optical density at $620 \mathrm{~nm}$ of $0.40 \pm 0.01$. Two drops of this suspension were added to each cupule, and the API ZYM strips were incubated for $4 \mathrm{~h}$ at $35^{\circ} \mathrm{C}$. Reagents were added, and the reactions were interpreted according to the instructions of the manufacturer.
Motility. Broth cultures that were $3 \mathrm{~h}$ old were examined for motile cells by phase-contrast microscopy. Strains were also tested for migration through CSS soft agar which was dispensed into tubes (12 by $100 \mathrm{~mm}$ ) and stored in the anaerobic chamber until the resazurin indicator became colorless. Several colonies of each strain were inoculated into the top 5 to $10 \mathrm{~mm}$ of medium. After 6 days of incubation, the distance from the meniscus of the agar to the advancing front of bacterial cells was measured. Migration through soft agar was interpreted as follows: negative, $<15$ $\mathrm{mm}$; intermediate, 15 to $40 \mathrm{~mm}$; positive, $>40 \mathrm{~mm}$.

Flagellum stains were prepared by the Ryu method (16).

Gas-liquid chromatography. After incubation for 5 days, culture samples were prepared for gas-liquid chromatography by methods adapted from methods described in the Anaerobe Laboratory Manual (13); these samples were analyzed on a chromatograph equipped with a flame ionization detector. The presence of less than 1 meq of acid per 100 $\mathrm{m}$ l was considered minor acid production, and the presence of more than $1 \mathrm{meq}$ of acid per $100 \mathrm{ml}$ was considered major acid production.

Gas-liquid chromatography was performed on samples of sham-inoculated media to determine the background levels of acetic, lactic, and succinic acids. If the concentration of any of these acids exceeded the background level by $20 \%$, this was regarded as acid production.

Electron microscopy. The organisms were grown in CSS broth for $72 \mathrm{~h}$. To prepare negative stains, $1 \mathrm{ml}$ of a cell suspension was mixed with an equal volume of cold $1 \%$ glutaraldehyde in cacodylate buffer. Grids were prepared and stained with uranyl acetate. The remainder of the cells were harvested by centrifugation. Each cell pellet was fixed as described above, postfixed in $1 \%$ osmium tetroxide, and embedded in a mixture of Epon and Araldyte. Sections were stained with lead citrate. The grids were examined with a Philips model EM 400 electron microscope.

DNA purification. To prepare deoxyribonucleic acid (DNA), each strain was grown in 500 to $1,000 \mathrm{ml}$ of broth for 5 days at $35^{\circ} \mathrm{C}$ in an anaerobic environment. The curved vaginal rod-shaped bacteria were grown in CSS broth supplemented with $0.04 \%$ cysteine hydrochloride. Starch and rabbit serum were replaced by $0.2 \%$ sodium formate and $0.3 \%$ fumaric acid for growth of Campylobacter, Wolinella, and $B$. gracilis, by $0.3 \%$ arginine hydrochloride for growth of Eubacterium lentum, and by $1 \%$ glucose for growth of all other organisms. The $\mathrm{pH}$ of each medium was adjusted to 7.0 \pm 0.2 . The bacterial cells were harvested by centrifugation at $4,810 \times g$ for $10 \mathrm{~min}$ at $4^{\circ} \mathrm{C}$. The resulting cell pellets were frozen at either -70 or $-20^{\circ} \mathrm{C}$ until they were needed.

The DNA extraction methods of So et al. (31) and P. A. Totten (personal communication) were modified for our use. Approximately one-quarter of a cell pellet was suspended in $40 \mathrm{ml}$ of TE [0.15 M tris(hydroxymethyl)aminomethane, 0.1 M ethylenediaminetetraacetic acid, pH 8.0], $40 \mathrm{mg}$ of lysozyme was added, and the mixture was incubated at $37^{\circ} \mathrm{C}$ for $1 \mathrm{~h}$. Then $10 \mathrm{mg}$ of pronase (Sigma) was added, and the mixture was incubated at $55^{\circ} \mathrm{C}$ for $30 \mathrm{~min}$. Sodium dodecyl sulfate was added to a final concentration of $0.4 \%$, and the mixture was heated at $55^{\circ} \mathrm{C}$ until the cells were lysed ( 1 to 2 h). The solution was diluted 1:1 with TE, $2 \mathrm{mg}$ of proteinase $\mathrm{K}$ (Sigma) was added, and the mixture was incubated overnight at $37^{\circ} \mathrm{C}$. The suspension was mixed with an equal volume of tris(hydroxymethyl)aminomethane-saturated phenol $\left(\mathrm{pH} \mathrm{8.0)}\right.$ and centrifuged at $2,400 \times g$ for $5 \mathrm{~min}$ at $4^{\circ} \mathrm{C}$. The aqueous phase was mixed with an equal volume of chloroform and centrifuged at $2,400 \times g$ for $5 \mathrm{~min}$ at $4^{\circ} \mathrm{C}$. The 
aqueous phase was reextracted with chloroform. The DNA was precipitated with $0.3 \mathrm{M}$ sodium acetate and cold ethanol and collected by centrifugation at $14,000 \times g$ for $20 \mathrm{~min}$ at $4^{\circ} \mathrm{C}$. The pellet was suspended in $0.1 \times \mathrm{SSC}(0.015 \mathrm{M} \mathrm{NaCl}$ plus $0.0015 \mathrm{M}$ sodium citrate), and $\mathrm{NaCl}$, ethylenediaminetetraacetic acid, and tris(hydroxymethyl)aminomethane were added to final concentrations of $0.1,0.05$, and 0.025 $\mathrm{mM}$, respectively. Boiled ribonuclease (500 $\mathrm{mg}$; Sigma) was added, and the mixture was incubated at $60^{\circ} \mathrm{C}$ for $1 \mathrm{~h}$. The DNA was extracted twice with chloroform-isoamyl alcohol (24:1) and precipitated with sodium acetate and cold ethanol. The DNA was suspended in $0.1 \times \mathrm{SSC}$ and dialyzed against $0.42 \mathrm{M} \mathrm{NaCl}$ or other buffers, as described below. For hybridization, the DNA was sheared by sonication (4).

DNA-DNA hybridization. DNA was isolated from each of the 35 strains. The DNAs from four strains were labeled by nick translation, using $0.5 \mu \mathrm{g}$ of DNA and $\left[{ }^{3} \mathrm{H}\right]$ thymine $5^{\prime}$ triphosphate, as described by Maniatis et al. (20); these DNAs were used as probes. The labeled DNAs were diluted to concentrations of $5,000 \mathrm{cpm} / 10 \mu \mathrm{l}$. Test DNA $(15 \mu \mathrm{g})$ and $10 \mu$ l of radioactive probe DNA were mixed, denatured in a total volume of $300 \mu \mathrm{l}$, and then allowed to hybridize overnight at $65^{\circ} \mathrm{C}$. The amount of reassociation between the probe DNA and the test DNA was assayed with S1 endonuclease as previously described (4). The levels of reassociation of unlabeled homologous DNA and unlabeled heterologous DNA (calf thymus DNA) with each labeled probe DNA served as controls in each experiment. The heterologous control measured the amount of self-annealing of the probe $(\leq 11 \%)$, and this value was subtracted from all other values. The homologous control always had $\geq 77 \%$ of the total probe activity. Test results were normalized to $100 \%$ for the homologous DNAs.

Determination of thermal melting profiles. DNAs from the four vaginal curved rod-shaped organisms used as probes and an Escherichia coli control $(\mathrm{G}+\mathrm{C}$ content, $51 \mathrm{~mol} \%)$ were dialyzed against 4 liters of $0.5 \times \operatorname{SSC}(0.075 \mathrm{M} \mathrm{NaCl}$ plus $0.0075 \mathrm{M}$ sodium citrate, $\mathrm{pH} 7.0$ ). The melting profiles were determined as described by Johnson (15), using a Gilford model 250 automatic recording spectrophotometer equipped with a heated cuvette holder. Escherichia coli was used as an internal standard for each experiment. Analyses were done in triplicate over a 1-week period.

Decarboxylase and dihydrolase activity. Cultures were grown for 4 days in peptone-starch-dextrose broth supplemented with $0.1 \%$ arginine hydrochloride and in peptonestarch-dextrose broth supplemented with $0.1 \%$ lysine hydrochloride and $0.1 \%$ ornithine hydrochloride (3). The media were adjusted to $\mathrm{pH} 6.0$ before autoclaving and were supplemented with $2 \%$ rabbit serum after autoclaving. The spentculture media were filter-sterilized, and the cell-free supernatants were tested for putrescine, cadaverine, ornithine, and citrulline by using the thin-layer chromatographic methods of Chen et al. (3).

\section{RESULTS AND DISCUSSION}

All of the vaginal strains were curved, motile, anaerobic, rod-shaped organisms. These strains were either small (mean cell length, $1.7 \mu \mathrm{m}$ ) or large (mean cell length, 2.9 $\mu \mathrm{m})$. No spores were detected, as determined by ethanol resistance of cultures (18) or by staining of cultures after 14 to 16 days of growth on chopped meat agar slants incubated anaerobically at $30^{\circ} \mathrm{C}$. The strains were weakly $(\mathrm{pH} 5.5$ to $6.5)$ or strongly $(\mathrm{pH}<5.5)$ saccharolytic. The fermentation products included succinic and acetic acids, with or without lactic acid. All strains grew at 35 and $42^{\circ} \mathrm{C}$ but not at $45^{\circ} \mathrm{C}$.
Some strains survived incubation at $25^{\circ} \mathrm{C}$. These organisms grew at $\mathrm{pH} 6.0$ to 7.2 and varied in their ability to grow at $\mathrm{pH}$ 5.0 and 7.9. They grew in the presence of $1 \% \mathrm{NaCl}$, but were partially or totally inhibited by $2 \% \mathrm{NaCl}$. When stained by the Kopeloff modification of the Gram stain (13), the strains of the small cell type were gram variable. Young cultures were more likely to appear to be gram positive. The strains of the large cell type were gram negative. Multiple lateral flagella were observed after flagellum staining of all 22 strains. Clusters of two to six flagella which were longer than the bacterial cells were observed in electron micrographs (Fig. 1A). A subterminal attachment site was sometimes observed (Fig. 1B).

Although the Gram reactions of the curved rod-shaped organisms were variable, electron micrographs of both groups revealed multilayered gram-positive cell walls lacking an outer membrane (Fig. 1C and D). Similar multilayered walls have been described for both gram-negative (21) and gram-positive (30) organisms. Gardnerella vaginalis, another gram-variable organism from human vaginae, also has a multilayered wall (10). The thinness of the peptidoglycan layer may explain the tendency of the curved rod-shaped organisms to stain gram negative. Cytoplasmic, spherical, electron-dense inclusions which may represent storage granules (27) or accumulations of phage heads were observed in all three strains examined (data not shown).

The apparent absence of an outer membrane suggests that the curved rod-shaped organisms more closely resemble gram-positive organisms than gram-negative organisms. This conclusion is supported by reports that these organisms are resistant to colistin and nalidixic acid (7) and are susceptible to penicillin (35) and vancomycin (unpublished data). Hydroxy fatty acids, which are commonly found in gramnegative cell walls, are absent from these organisms (28).

Although we originally described the curved rod-shaped bacteria of vaginal origin as asaccharolytic, we now have shown that these strains can reduce the $\mathrm{pH}$ values of media supplemented with rabbit serum. Growth in PY broth was improved by adding glycogen or maltose, carbohydrates which are found in human vaginae. More acetic acid and succinic acid were produced in PY broth supplemented with rabbit serum and glycogen than in PY broth supplemented with rabbit serum and glucose or in PY broth supplemented with rabbit serum alone. None of the strains was stimulated by formate-fumarate. When they were grown in the presence of formate-fumarate without rabbit serum, all strains produced a nonvolatile peak corresponding to methylmalic acid, which eluted at about 4.5 times the $R_{f}$ of methylsuccinate. The identity of this compound was verified by mass spectrometry, and its production was not enhanced by rabbit serum.

The vaginal curved rod-shaped bacteria are different from members of the family Propionibacteriaceae. Neither Propiobacterium spp. nor Eubacterium spp. produce succinic acid or have polar flagella, and Propionibacterium spp. have $\mathrm{G}+\mathrm{C}$ contents of 59 to $66 \mathrm{~mol} \%$. Previously described genera that produce succinate can also be differentiated from the vaginal curved rod-shaped organisms, as follows: Actinomyces spp. are nonmotile and have $\mathrm{G}+\mathrm{C}$ contents of 60 to $63 \mathrm{~mol} \%$; Anaerobiospirillum succiniciproducens is a large (length $20-\mu \mathrm{m}$ ) spiral organism with a $\mathrm{G}+\mathrm{C}$ content of 44 mol\%; Bacteroides spp. are either nonmotile or have peritrichous flagella; Campylobacter spp. are asaccharolytic, oxidase positive, have single polar flagella, and have $\mathrm{G}+\mathrm{C}$ contents of 30 to $35 \mathrm{~mol} \%$; Succinimonas amylolytica cells are not curved and have single polar flagella; Succinivibrio 


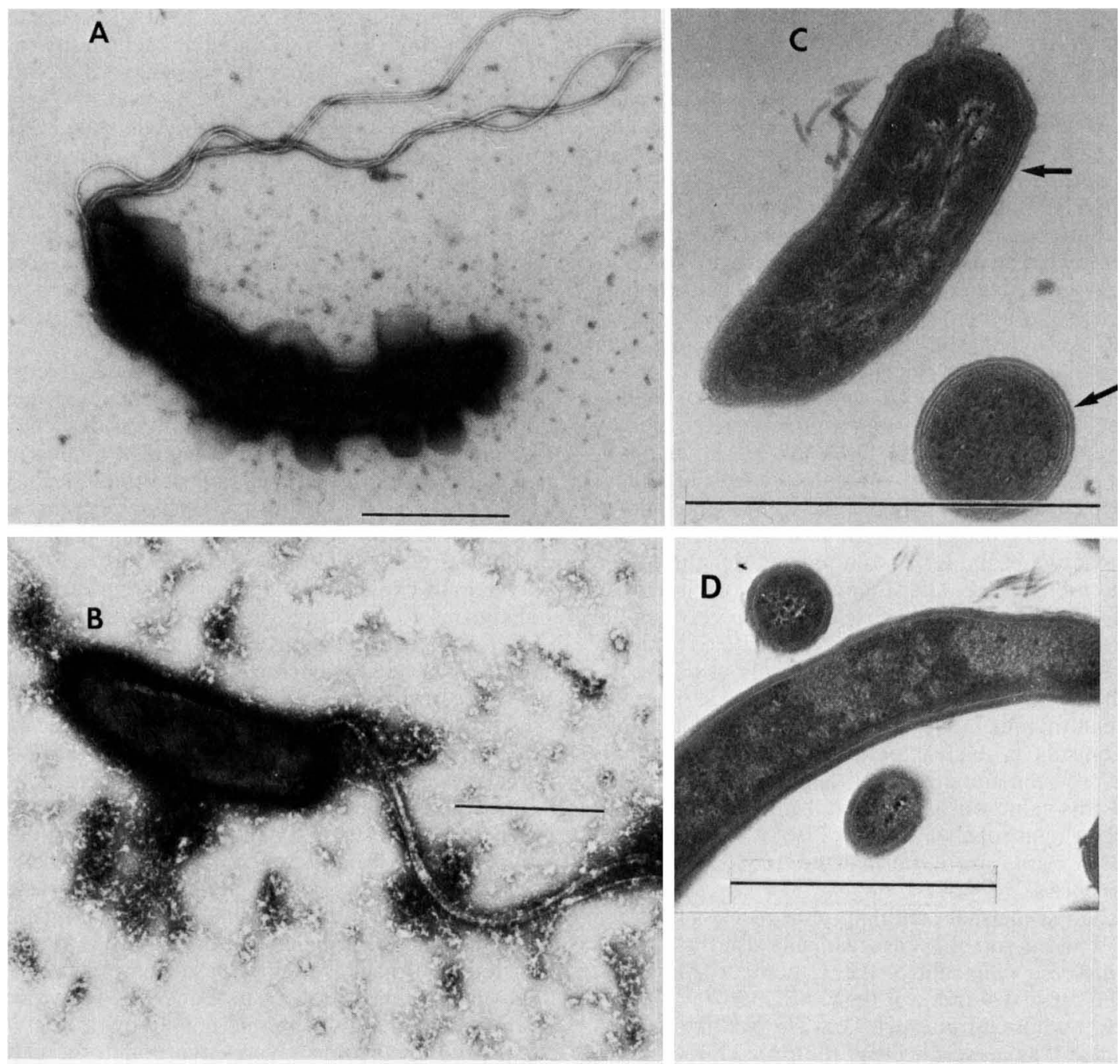

FIG. 1. Electron micrographs of Mobiluncus spp. (A) Negatively stained $M$. curtisii subsp. curtisii BV345-16 ${ }^{\mathrm{T}}$ cell showing flagella. The flagella appear to originate subterminally (at the right). The blebs on the cell surface are artifacts of fixation but may have occurred because of the thin peptidoglycan layer (see below). Bar $=1 \mu \mathrm{m}$. (B) Negatively stained $M$. curtisii subsp. holmesii BV376-6 ${ }^{\mathrm{T}}$ cell showing subterminal attachment of the flagella. Bar $=1 \mu \mathrm{m}$. (C) Thin section of $M$. curtisii subsp. curtisii BV $345-16^{T}$ cells showing the multilayered wall that is not clearly typical of gram-positive cell wall structure in both longitudinal section and cross-section (arrows). Bar $=1 \mu \mathrm{m}$. (D) Thin section of $M$. mulieris BV27-6 cells showing the atypical multilayered gram-positive cell wall structure. Bar $=1 \mu \mathrm{m}$.

dextrinosolvens cells have single polar flagella; and Wolinella spp. are asaccharolytic, exhibit growth that is stimulated by formate-fumarate, have single polar flagella, and have $\mathrm{G}+\mathrm{C}$ contents of 42 to $49 \mathrm{~mol} \%$. To our knowledge, the $\mathrm{G}+\mathrm{C}$ contents of Succinimonas amylolytica and Succinivibrio dextrinosolvens have not been determined. We found less than 1\% DNA homology between the 4 probes and the other 13 strains examined, including the type strains of Actinomyces bovis, Actinomyces odontolyticus, Anaerovibrio lipolytica, Anaerobiospirillum succiniciproducens, Campylobacter fetus subsp. venerealis, Campylobacter concicus, and Selenomonas sputigena (see above).

Therefore, we propose a new genus, Mobiluncus, for the vaginal isolates. Although the characteristics of the vaginal isolates exclude them from the Actinomycetaceae, the Bacteroidaceae, and the Propionibacteriaceae, they are most similar to the Bacteroidaceae. We tentatively place two species of the new genus Mobiluncus in the family Bacteroidaceae, which includes other genera of curved, anaerobic, rod-shaped organisms that are gram negative, have polar flagella, and produce succinic acid. The levels of DNA homology were $>75 \%$ within and $\leq 25 \%$ between strains of the two species (Table 1).

Mobiluncus gen. nov. Mobiluncus (mo.bi.lun'cus. L. adj. mobilis capable of movement, active; L. masc. n. uncus a hook; N.L. masc. n. Mobiluncus a motile curved rod) cells are anaerobic, gram variable or gram negative, curved, nonsporing, and rod shaped with tapered ends, occurring singly or in pairs with a gullwing appearance. They are motile by means of multiple subpolar flagella and possess a multilayered gram-positive type of cell wall.

Weakly (terminal $\mathrm{pH}, 5.5$ to 6.5 ) or strongly (terminal $\mathrm{pH}$, $<5.5)$ saccharolytic. Fermentation products include succinic and acetic acids, with or without lactic acid. Growth is stimulated by rabbit serum. Growth is not stimulated by formate-fumarate. Oxidase and catalase are not produced.

The described species are found in human vaginae associated with bacterial vaginosis (nonspecific vaginitis). 
TABLE 1. Relative levels of DNA sequence homology among $M$. curtisii and $M$. mulieris strains

\begin{tabular}{|c|c|c|c|c|}
\hline \multirow[b]{2}{*}{ Strain } & \multicolumn{4}{|c|}{$\%$ Homology with DNA from: } \\
\hline & $\begin{array}{c}\text { M. curtisii } \\
\text { subsp. curtisii } \\
\text { BV345-16 }\end{array}$ & $\begin{array}{c}\text { M. curtisii } \\
\text { subsp. holmesii } \\
\text { BV376-6 }\end{array}$ & $\begin{array}{l}\text { M. mu- } \\
\text { lieris } \\
\text { SV17 } \mathrm{J}^{\mathrm{T}}\end{array}$ & $\begin{array}{c}\text { M. mu- } \\
\text { lieris } \\
\text { BV64-5 }\end{array}$ \\
\hline \multicolumn{5}{|c|}{$\begin{array}{l}\text { M. curtisii subsp. } \\
\text { curtisii }\end{array}$} \\
\hline BV13-6 & 96 & 86 & 22 & 19 \\
\hline BV67-5 & 100 & 95 & 22 & 18 \\
\hline BV105-4 & 97 & 95 & 15 & 20 \\
\hline BV $345-16^{\mathrm{T}}$ & 100 & 90 & 22 & 22 \\
\hline BV416-10 & 99 & 91 & 12 & 13 \\
\hline BV424-9 & 101 & 90 & 17 & 15 \\
\hline \multicolumn{5}{|c|}{$\begin{array}{l}\text { M. curtisii subsp. } \\
\text { holmesii }\end{array}$} \\
\hline BV306-7 & 84 & 100 & 9 & 16 \\
\hline BV $376-6^{\mathrm{T}}$ & 88 & 100 & 19 & 11 \\
\hline SV34N & 85 & 102 & 18 & 21 \\
\hline SV $40 Q$ & 82 & 95 & 14 & 14 \\
\hline SV51R & 92 & 102 & 19 & 10 \\
\hline \multicolumn{5}{|l|}{ M. mulieris } \\
\hline SV17 $J^{\mathrm{T}}$ & 24 & 17 & 100 & 94 \\
\hline SV58S & 22 & 17 & 89 & 79 \\
\hline 2471 & 23 & 25 & 75 & 87 \\
\hline 2472 & 22 & 9 & 83 & 100 \\
\hline 2473 & 19 & 15 & 87 & 94 \\
\hline BV27-6 & 23 & 21 & 76 & 89 \\
\hline BV64-5 & 21 & 22 & 85 & 100 \\
\hline SV45E2 & 25 & 23 & 83 & 96 \\
\hline SV52T & 25 & 13 & 83 & 88 \\
\hline BV26-9 & 12 & 12 & 88 & 81 \\
\hline
\end{tabular}

The $\mathrm{G}+\mathrm{C}$ content ranges from 49 to $52 \mathrm{~mol} \%$, as determined by the thermal melting method.

The type species is Mobiluncus curtisii.

Mobiluncus curtisii subsp. curtisii sp. nov. Mobiluncus curtisii subsp. curtisii (cur.ti'si.i. N.L. gen. n. curtisii named after A. H. Curtis, who isolated the first strain) cells are anaerobic, gram variable, curved, nonsporing, rod shaped, and motile by means of multiple subterminal flagella. The cells are $<0.5 \mu \mathrm{m}$ wide and have a mean length of $1.7 \mu \mathrm{m}$ (Fig. 2A). Cells migrate through soft $(0.25 \%)$ agar. Colonies are colorless, translucent, smooth, convex, and entire and reach a maximum diameter of 2 to $3 \mathrm{~mm}$ after 5 days of incubation.

Growth is stimulated by arginine. Starch and hippurate are hydrolyzed in the absence of serum. Citrulline, ornithine, and ammonia are produced from arginine. Weakly ( $\mathrm{pH} 5.5$ to 6.5 ) to strongly ( $\mathrm{pH}<5.5$ ) saccharolytic (Table 2). Cultures are more turbid in PY broth supplemented with rabbit serum and glycogen or maltose than in PY broth supplemented with glucose and rabbit serum or rabbit serum alone. Other biochemical characteristics are shown in Table 2 . The fermentation products from glycogen include succinate $(>1$ $\mathrm{meq} / 100 \mathrm{ml})$, trace amounts of fumarate $(<1 \mathrm{meq} / 100 \mathrm{ml})$, and moderate amounts of acetate $(<1 \mathrm{meq} / 100 \mathrm{ml})$.

Alpha-glucosidase (10 to $30 \mathrm{nmol}$ of product), phosphoamidase ( $\leq 5 \mathrm{nmol})$, and leucine aminopeptidase (5 to 10 $\mathrm{nmol})$ are produced. Esterase lipase $(<5 \mathrm{nmol})$ is produced by five of six strains, acid phosphatase is produced by one strain, $\alpha$-galactosidase is produced by two strains, and alkaline phosphatase is produced by one strain. Butyrate esterase, lipase, valine aminopeptidase, cystine aminopeptidase, trypsin, chymotrypsin, $\beta$-glucuronidase, $\beta$-glucosi- dase, $N$-acetyl- $\beta$-glucosamidase, $\alpha$-mannosidase, and $\alpha$-fucosidase are not produced at 35 or $42^{\circ} \mathrm{C}$.

Nitrate is not reduced to nitrite. A weak CAMP reaction (Fig. 3) is produced on brucella agar supplemented with $5 \%$ sheep blood when Staphylococcus aureus ATCC 25923 is used.

The $\mathrm{G}+\mathrm{C}$ content of the DNA is 51 to $52 \mathrm{~mol} \%$, as determined by the thermal melting method.

Isolated from human vaginae; associated with bacterial vaginosis.

The type strain is strain BV345-16 (= ATCC 35241).

Mobiluncus curtisii subsp. holmesii subsp. nov. The characteristics and sources of Mobiluncus curtisii subsp. holmesii (holme'si.i. N.L. gen. n. holmesii named after K. K. Holmes, a researcher of sexually transmitted diseases) are similar to those of $M$. curtisii subsp. curtisii except as follows. Cells do not migrate through soft $(0.25 \%)$ agar. Weakly saccharolytic (pH 5.5 to 6.5 ) (Table 2). The fermentation products from glycogen in the presence of serum include trace amounts of pyruvate $(<1 \mathrm{meq} / 100 \mathrm{ml})$. Trace amounts of oxaloacetate $(<1 \mathrm{meq} / 100 \mathrm{ml})$ are produced by five of six strains.

Esterase lipase ( $\leq 5 \mathrm{nmol}$ ) is produced by all strains. $\beta$ Galactosidase and $\alpha$-galactosidase are produced by two of six strains, and alkaline phosphatase is produced by one of six strains.

Nitrate is reduced to nitrite.

The type strain is strain BV376-6 (= ATCC 35242).

Mobiluncus mulieris sp. nov. Mobiluncus mulieris (mu. li.e'ris. L. gen. n. mulieris of a woman; from "Vibrio mulieris," which was suggested by Prévot [26]) cells are anaerobic, gram negative, curved, nonsporing, rod shaped, and motile by means of multiple subterminal flagella. Migration through soft $(0.25 \%)$ agar is variable. The cells are $<0.5$ $\mu \mathrm{m}$ wide and have a mean length of $2.9 \mu \mathrm{m}$ (Fig. 2B). Colonies are colorless, translucent, smooth, convex, and entire and reach a maximum diameter of 2 to $3 \mathrm{~mm}$ after 5 days of incubation.

Growth is not stimulated by arginine. Hippurate is not hydrolyzed. Citrulline, ornithine, and ammonia are not produced from arginine. Starch is hydrolyzed in the absence of serum. Strongly saccharolytic $(\mathrm{pH}<5.5)$. Cultures are more turbid in PY broth supplemented with rabbit serum and glycogen or maltose than in PY broth supplemented with rabbit serum and glucose or in PY broth supplemented with rabbit serum alone. Other biochemical characteristics are shown in Table 2 . The fermentation products from glycogen include succinate $(>1 \mathrm{meq} / 100 \mathrm{ml})$, acetate $(>1 \mathrm{meq} / 100 \mathrm{ml})$, and trace amounts of fumarate $(<1 \mathrm{meq} / 100 \mathrm{ml}) ; 8$ of 10

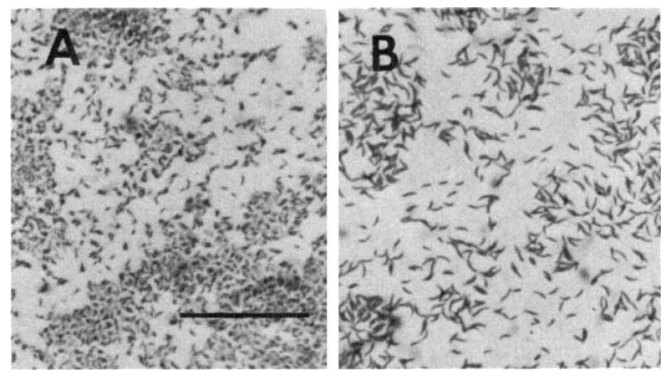

FIG. 2. Gram stains of Mobiluncus spp. The cells were $<0.5 \mu \mathrm{m}$ wide. (A) Gram-variable cells of $M$. curtisii. The mean cell length was $1.7 \mu \mathrm{m}$. Bar $=20 \mu \mathrm{m}$. (B) Gram-negative cells of $M$. mulieris. The mean cell length was $2.9 \mu \mathrm{m}$. 


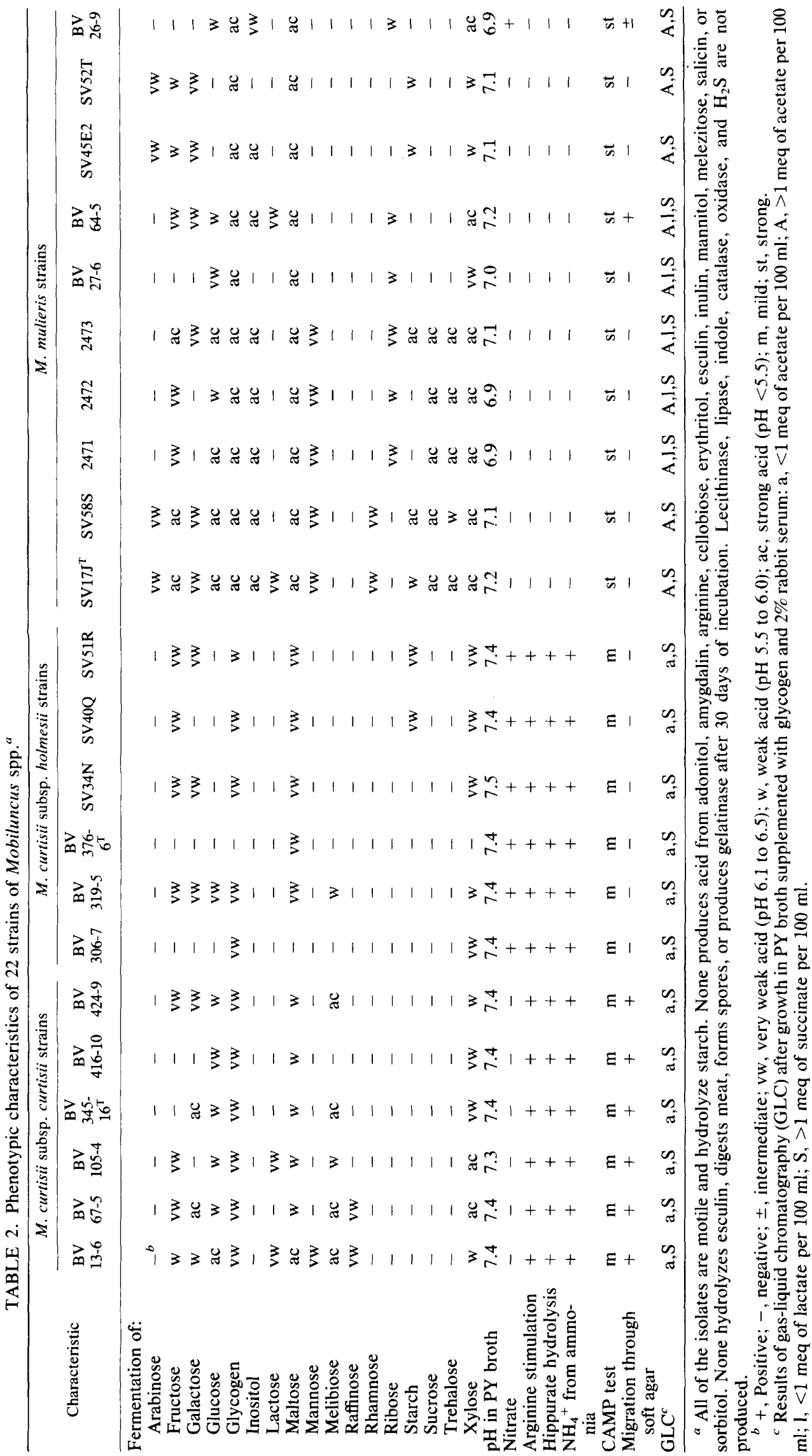




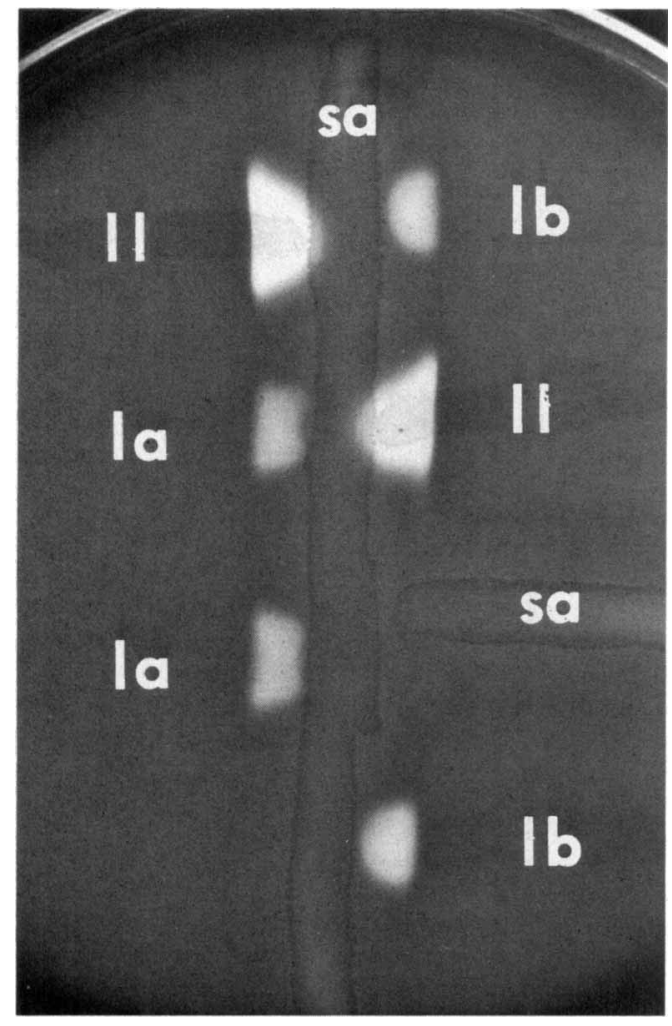

FIG. 3. CAMP reactions showing weak enhancement of hemolysis by $M$. curtisii subsp. curtisii (Ia) and $M$. curtisii subsp. holmesii (Ib) and strong enhancement of hemolysis by $M$. mulieris (II). Staphylococcus aureus ATCC 25923 (sa) was included as a negative control.

strains produce trace amounts of oxaloacetate $(<1 \mathrm{meq} / 100$ $\mathrm{ml}), 6$ of 10 strains produce trace amounts of pyruvate $(<1$ meq $/ 100 \mathrm{ml})$, and 5 of 10 strains produce trace amounts of lactate $(<1 \mathrm{meq} / 100 \mathrm{ml})$.

Alpha-glucosidase ( 15 to $\geq 40 \mathrm{nmol}$ of product), phosphoamidase $(\leq 5 \mathrm{nmol})$, leucine aminopeptidase $(<5$ to $20 \mathrm{nmol})$, and esterase lipase $(<5 \mathrm{nmol})$ are produced. Acid phosphatase is produced by 1 of 10 strains. Butyrate esterase, lipase, valine aminopeptidase, cystine aminopeptidase, trypsin, chymotrypsin, $\beta$-glucuronidase, $\beta$-glucosidase, $N$-acetyl- $\beta$ glucosamidase, $\alpha$-mannosidase, and $\alpha$-fucosidase are not produced at 35 or $42^{\circ} \mathrm{C}$.

Nitrate is reduced to nitrite by 1 of 10 strains. A strong CAMP reaction (Fig. 3) is produced on brucella agar supplemented with $5 \%$ sheep blood when Staphylococcus aureus ATCC 25923 is used.

The $\mathrm{G}+\mathrm{C}$ content is 49 to $50 \mathrm{~mol} \%$.

The type strain is strain SV17J (= ATCC 35243).

The salient characteristics which differentiate $M$. curtisii from $M$. mulieris are shown in Table 3.

Although our strains of $M$. curtisii and $M$. mulieris appear to differ from many of the European strains described previously, these differences may only reflect variations in methods. The three Belgian strains characterized in this study were $M$. mulieris strains. We tested seven additional strains sent to us by A. Skarin. One was a $M$. curtisii subsp. curtisii strain, three were $M$. curtisii subsp. holmesii strains, and three were $M$. mulieris strains. The levels of DNA relatedness of phenotypically similar strains reported by Mårdh et al. (P.-A. Mårdh, G. Christensen, E. Holst, L. Larsson, B. R. Moller, A. Skarin, and I. Thelin, Abstr. Int.
Soc. Sex. Transmit. Dis. Res. V, Seattle, Wash., 1983 , Abstr. 24, p. 56) differ only within the expected analytical error. The $\mathrm{G}+\mathrm{C}$ contents reported here are 3 to $4 \mathrm{~mol} \%$ lower than the $\mathrm{G}+\mathrm{C}$ content reported for a strain phenotypically similar to $M$. mulieris that was examined by Peloux and Thomas (23), who used the buoyant density method.

Our observation of arginine utilization by $M$. curtisii but not by $M$. mulieris supports the independent observations of Sprott et al. (35). Because the Eh (oxidation-reduction potential) decreases $60 \mathrm{U}$ when the $\mathrm{pH}$ increases $1 \mathrm{U}$, production of ammonia in vivo makes the environment more anaerobic. Other organisms present in the vaginal flora which also produce ammonia from arginine include Streptococcus spp. (5) and the mycoplasmata (2). Holst et al. (14) noted that pure cultures of the curved rod-shaped organisms smelled of cat urine. This may be attributable to the ammonia.

Because $M$. curtisii and $M$. mulieris do not produce putrescine or cadaverine in peptone-starch-dextrose broth supplemented with lysine and ornithine, these species apparently are not the source of the amine odor associated with bacterial vaginosis.

In studies of similar vaginal organisms, Hjelm et al. (12) detected production of butyrate esterase by 10 of 11 strains and production of acid phosphatase by 7 of 11 strains. Holst et al. detected leucine aminopeptidase only in long variant $(M$. mulieris) strains and butyrate esterase in all strains (14). We detected leucine aminopeptidase in six of seven strains sent to us by Skarin, four of which were the short variant $(M$ curtisii). Differences in our results may reflect differences in growth media or concentrations of inocula.

$M$. mulieris but not $M$. curtisii gave a strongly positive CAMP test on brucella agar supplemented with $5 \%$ sheep blood (Fig. 3). There was minimal stimulation of hemolysis by strains of either species when the CAMP test was performed on human blood bilayer-Tween agar (36) or on brucella agar supplemented with 5 or $10 \%$ horse or rabbit blood. Peloux and Thomas demonstrated a similar phenomenon by using Clostridium perfringens (23) and four strains that probably were $M$. mulieris strains.

Extracellular capsular material as detected by electron microscopy was associated only with $M$. curtisii subsp. holmesii.

The starch, maltose, and trehalose reactions are unreliable in the presence of serum because of the hydrolytic action of

TABLE 3. Differential characteristics of Mobiluncus spp.

\begin{tabular}{|c|c|c|c|}
\hline Characteristic & $\begin{array}{l}\text { M. curtisii } \\
\text { subsp. } \\
\text { curtisii }\end{array}$ & $\begin{array}{l}\text { M. curtisii } \\
\text { subsp. } \\
\text { holmesii }\end{array}$ & M. mulieri. \\
\hline Length of cells $(\mu \mathrm{m})$ & 1.7 & 1.7 & 2.9 \\
\hline Gram reaction & Variable & Variable & Negative \\
\hline Stimulated by arginine & $+^{a}$ & + & - \\
\hline $\mathrm{NH}_{4}^{+}$from arginine & + & + & - \\
\hline Hippurate hydrolyzed & + & + & - \\
\hline CAMP reaction & Weak & Weak & Strong \\
\hline $\begin{array}{l}\text { Produces }>1 \text { meq of acetate } \\
\text { per } 100 \mathrm{ml}\end{array}$ & - & - & + \\
\hline Acid ( $\mathrm{pH}<5.5$ ) from glycogen & - & - & + \\
\hline $\begin{array}{l}\text { Acid }(\mathrm{pH} \leq 6.0) \text { from } \\
\text { melibiose }\end{array}$ & $+(-)$ & $-(+)$ & - \\
\hline Nitrate reduced & - & + & $-(+)$ \\
\hline Migrates through soft agar & + & - & $\mathrm{v}$ \\
\hline Acid $(\mathrm{pH}<5.5)$ from trehalose & - & - & $\mathrm{v}$ \\
\hline
\end{tabular}

${ }^{a}+$, Positive; - , negative; $+(-)$, usually positive; $-(+)$, usually negative; $v$, variable. 
serum. All of the strains hydrolyzed starch broth in the absence of serum within 10 days. Starch hydrolysis was also detected as clearing of starch agar (3.5\% Columbia broth, $1 \%$ proteose peptone no. $3,0.75 \%$ glucose, $1 \%$ corn starch, and $1.5 \%$ agar) after incubation for 4 days. Starch is hydrolyzed either to maltose by amylase or to D-glucose by amyloglucosidase. Therefore, starch-hydrolyzing organisms that produce acid from glucose or maltose would be expected to produce acid from starch. The reasons why this pattern was not demonstrated by all strains of Mobiluncus are unknown.

\section{ACKNOWLEDGMENTS}

We are indebted to Kirk C. S. Chen, University of Washington, for thin-layer chromatography, Anthony Wu, Medical College of Wisconsin, for mass spectrometry, T. O. MacAdoo, Virginia Polytechnic Institute and State University, for aid in the selection of correct names for the organisms, and Peter Perine, King K. Holmes, and Patricia Totten for providing laboratory space and technical advice.

This work was supported in part by a grant from the National Foundation for Infectious Diseases, by Public Health Service grant 507 RR05434 from the National Institutes of Health, and by Public Health Service Sexually Transmitted Disease Research Program Project grant AI12192 from the National Institutes of Health. M.R. was also supported by a Public Health Service New Investigators Research Award (AI 17761) from the National Institute of Allergy and Infectious Diseases.

\section{ADDENDUM IN PROOF}

$M$. curtisii subsp. holmesii strain BV319-5 was examined for percent homology with the four strains of Mobiluncus spp. used as probes, but the data have been deleted from Table 1 because we have reason to doubt the purity of the culture. We are currently reexamining this strain.

\section{LITERATURE CITED}

1. Amsel, R., P. A. Totten, C. A. Spiegel, K. C. S. Chen, D. Eschenbach, and K. K. Holmes. 1983. Nonspecific vaginitis: diagnostic criteria and microbial and epidemiologic associations. Am. J. Med. 74:14-22.

2. Ball, H. J., S. D. Neill, and L. R. Reid. 1982. Use of arginine aminopeptidase activity in characterization of arginine-utilizing mycoplasmas. J. Clin. Microbiol. 15:28-34.

3. Chen, K. C. S., N. J. Culbertson, J. S. Knapp, G. E. Kenny, and K. K. Holmes. 1982. Rapid method for simultaneous detection of the arginine dihydrolase system and amino acid decarboxylases in microorganisms. J. Clin. Microbiol. 16:909-919.

4. Crosa, J. H., D. J. Brenner, and S. Falkow. 1973. Use of a single-strand-specific nuclease for analysis of bacterial and plasmid deoxyribonucleic acid homo- and heteroduplexes. J. Bacteriol. 115:904-911.

5. Crow, V. L., and T. D. Thomas. 1982. Arginine metabolism in lactic streptococci. J. Bacteriol. 150:1024-1032.

6. Curtis, A. H. 1913. A motile curved anaerobic bacillus in uterine discharges. J. Infect. Dis. 12:165-169.

7. Durieux, R., and A. Dublanchet. 1980. Les "vibrions" anaérobies des leucorrhées. I. Technique d'isolement et sensibilité aux antibiotiques. Med. Mal. Infect. 10:109-115.

8. Facklam, R. R. 1980. Streptococci and aerococci, p. 88-110. In E. H. Lennette (ed.), Manual of clinical microbiology, 3 rd ed. American Society for Microbiology, Washington, D.C.

9. Gardner, H. L., and C. D. Dukes. 1955. Hemophilus vaginalis vaginitis. Am. J. Obstet. Gynecol. 69:962-976.

10. Greenwood, J. R., and M. J. Pickett. 1980. Transfer of Haemophilus vaginalis Gardner and Dukes to a new genus, Gardnerella: $G$. vaginalis (Gardner and Dukes) comb. nov. Int. J. Syst. Bacteriol. 30:170-178.

11. Hjelm, E., A. Hallén, U. Forsum, and J. Wallin. 1981. Anaerobic curved rods in vaginitis. Lancet ii:1353-1354.

12. Hjelm, E., A. Hallén, U. Forsum, and J. Wallin. 1982. Motile anaerobic curved rods in non-specific vaginitis. Eur. J. Sex. Trans. Dis. 1:9-14.
13. Holdeman, L. V., E. P. Cato, and W. E. C. Moore (ed.). 1977. Anaerobe laboratory manual, 4th ed. Virginia Polytechnic Institute and State University, Blacksburg.

14. Holst, E., A. Skarin, and P.-A. Mårdh. 1982. Characteristics of anaerobic comma-shaped bacteria recovered from the female genital tract. Eur. J. Clin. Microbiol. 1:310-316.

15. Johnson, J. L. 1981. Genetic characterization, p. 457-458. In P. Gerhardt (ed.), Manual of methods for general bacteriology. American Society for Microbiology, Washington, D.C.

16. Kodaka, H., A. Y. Armfield, G. L. Lombard, and V. R. Dowell. 1982. Practical procedure for demonstrating bacterial flagella. J. Clin. Microbiol. 16:948-952.

17. Kodaka, H., G. L. Lombard, and V. R. Dowell. 1982. Gas-liquid chromatography technique for detection of hippurate hydrolysis and conversion of fumarate to succinate by microorganisms. J. Clin. Microbiol. 16:962-964.

18. Koransky, J. R., S. D. Allen, and V. R. Dowell. 1978. Use of ethanol for selective isolation of sporeforming organisms. Appl. Environ. Microbiol. 35:762-765.

19. Krönig, I. 1895. Über die Natur der Scheidenheme, specielle über das vorkommen anaërober Streptokokken in Scheidensekret Schwangerer. Zentralbl. Gynaecol. 19:409-412.

20. Maniatis, T., A. Jeffrey, and D. G. Kleid. 1975. Nucleotide sequence of the right operator of phage $\lambda$. Proc. Natl. Acad. Sci. U.S.A. 72:1184-1188.

21. McInerney, M. J., M. P. Bryant, R. B. Hespell, and J. W. Costerton. 1981. Syntrophomonas wolfei gen. nov., sp. nov., an anaerobic, syntrophilic, fatty acid-oxidizing bacterium. Appl. Environ. Microbiol. 41:1029-1039.

22. Moore, B. 1954. Observations on a group of anaerobic vaginal vibrios. J. Pathol. Bacteriol. 67:461-473.

23. Peloux, Y., and P. Thomas. 1981. A propos de quelques bacteries mobiles anaerobies gram negatives. Rev. Inst. Pasteur Lyon 14:103-111.

24. Phillips, I., and E. Taylor. 1982. Anaerobic curved rods in vaginitis. Lancet $\mathbf{i}: 221$.

25. Popp, W. 1977. The diagnosis and treatment of mixed anaerobic vaginal discharges. Geburtshilfe Frauenheilkd. 37:432-437.

26. Prévot, A. R. 1940. Manuel de classification et de détermination des bactéries anaérobies. Masson et Cie, Paris.

27. Shively, J. M. 1974. Inclusion bodies of prokaryotes. Annu. Rev. Microbiol. 28:167-187.

28. Skarin, A., L. Larsson, E. Holst, and P.-A. Mårdh. 1982. Gas chromatographic study of cellular fatty acids of comma-shaped bacteria isolated from the vagina. Eur. J. Clin. Microbiol. 1:307309.

29. Skarin, A., and P.-A. Mårdh. 1982. Comma-shaped bacteria associated with vaginitis. Lancet $\mathbf{i}: 342-343$.

30. Sleytr, V. B., and A. M. Glauert. 1976. Ultrastructure of the cell walls of two closely related clostridia that possess different regular arrays of surface subunits. J. Bacteriol. 126:869-882.

31. So, M., J. H. Crosa, and S. Falkow. 1975. Polynucleotide sequence relationships among Ent plasmids and the relationship between Ent and other plasmids. J. Bacteriol. 121:234-238.

32. Spiegel, C. A., R. Amsel, D. Eschenbach, F. Schoenknecht, and K. K. Holmes. 1980. Anaerobic bacteria in nonspecific vaginitis. N. Engl. J. Med. 303:601-607.

33. Spiegel, C. A., R. Amsel, and K. K. Holmes. 1983. Diagnosis of bacterial vaginosis by direct Gram stain of vaginal fluid. J. Clin. Microbiol. 18:170-177.

34. Spiegel, C. A., D. A. Eschenbach, R. Amsel, and K. K. Holmes. 1983. Curved anaerobic bacteria in bacterial (nonspecific) vaginosis and their response to antimicrobial therapy. J. Infect. Dis. 148:817-822.

35. Sprott, M. S., H. R. Ingham, R. S. Pattman, R. L. Eisenstadt, G. R. Short, H. K. Narang, P. R. Sisson, and J. B. Selkon. 1983. Characteristics of motile curved rods in vaginal secretions. J. Med. Microbiol. 16:175-182.

36. Totten, P. A., R. Amsel, J. Hale, P. Piot, and K. K. Holmes. 1982. Selective differential human blood bilayer media for isolation of Gardnerella (Haemophilus) vaginalis. J. Clin. Microbiol. 15:141-147. 